\title{
Postoperative Peritoneal Adhesion Syndrome - a Challenging Issue in Laparoscopic Surgery
}

\author{
Simona Bobic', Dragos Davitoiu'', Adrian Dorin Bordei², Florian Popa'
}

\begin{abstract}
Introduction: The presence of the peritoneal adhesions during surgery represents an element that can negatively influence the intra- and postoperative evolution of the patients. This article aims to evaluate the impact of the peritoneal adhesions on the postoperative recovery of the patients. Material and method: The data of 1407 patients undergoing laparoscopic cholecystectomy between January 2014 and October 2018 were retrospectively analyzed. Patients were organized into two groups: the case group, consisting of patients for whom peritoneal adhesions were identified during the surgical intervention, and the control group, with patients that had no postoperative peritoneal adhesions. The degree of association between the presence of the peritoneal adhesions and the operative time, the risk of laparoscopic conversion to laparotomy and the risk of intra- or postoperative complications was analyzed. Results: For 537 patients (38.16\%) included in the study postoperative peritoneal adhesions were identified at the time of the laparoscopic cholecystectomy. A direct association was observed between the presence of postoperative peritoneal adhesions and the risk of conversion, a longer operative time or period of hospitalization and the risk of postoperative ileus. Conclusions: Postoperative peritoneal adhesions represent an independent risk factor for the increasing morbidity and mortality rates in patients undergoing laparoscopic cholecystectomy.
\end{abstract}

Keywords: laparoscopic cholecystectomy, peritoneal adhesions, burden, postoperative recovery.

\section{Rezumat}

Introducere: Obiectivarea aderențelor peritoneale în timpul intervenților chirurgicale constituie un element ce poate influența negativ evoluția intra- și postoperatorie a pacienților. Prezentul articol are drept scop evaluarea consecințelor aderențelor peritoneale asupra recuperării postoperatorii a pacienților. Material și metodă: Datele a 1407 pacienți supuși colecistectomiei laparoscopice, în perioada ianuarie 2014- octombrie 2018, au fost analizate retrospectiv. Pacienții au fost grupați în două loturi: lotul caz, format din pacienți la care s-a obiectivat intraoperator prezența aderențelor peritoneale postoperatorii, și lotul martor, format din pacienți fără aderențe peritoneale postoperatorii. S-a analizat gradul de asociere dintre aderențe și timpul operator, riscul de conversie a laparoscopiei la laparotomie și riscul complicațiilor intra- și postoperatorii. Rezultate: 537 de pacienți (38,16\%) incluși în studiu au prezentat aderențe peritoneale postoperatorii. S-a observat o asociere directă între prezența aderențelor peritoneale postoperatorii și riscul de conversie, prelungirea timpului operator, a perioadei de spitalizare și riscul apariției ileus-ului postoperator. Concluzii: Aderențele peritoneale postoperatorii reprezintă un factor de risc independent pentru creșterea morbidității și a mortalității pacienților supuși colecistectomiei laparoscopice.

Cuvinte cheie: colecistectomie laparoscopică, aderențe peritoneale, impact, recuperare postoperatorie

1 Department of General Surgery, "Sfantul Pantelimon" Emergency Hospital, „Carol Davila" University of Medicine and Pharmacy, Bucharest, Romania

2 Department of General Surgery, „Sfantul Pantelimon”

Emergency Hospital, Bucharest, Romania
Corresponding author.

Simona Bobic, Department of General Surgery, „Sfantul Pantelimon" Emergency Hospital, first floor, 340-342 Pantelimon Avenue, $2^{\text {nd }}$ District, Bucharest, Romania.

E-mail:simona.bobic@umfcd.ro/simona.bobic@yahoo.ca 


\section{INTRODUCTION}

It is difficult to evaluate the intra-and postoperative complications secondary to peritoneal adhesions identified during laparoscopic cholecystectomy. The Web of Science database was used in order to search for articles about laparoscopic cholecystectomy in patients with a personal history of abdominal or pelvic surgery, published over the past 10 years. The results of the search identified 9 articles published in English, highlighting the paucity of studies on this subject.

The postoperative peritoneal adhesions represent, for the majority of cases, an incidental finding during different surgical interventions, $90 \%$ being the reported incidence after abdominal and pelvic surgery ${ }^{1}$. Recent studies have shown a frequency rate of the intestinal obstruction secondary to peritoneal adhesions between $14 \%$ and $40 \%{ }^{2,3}$.

The incidence of the intestinal obstruction caused by peritoneal adhesions secondary to laparoscopic cholecystectomy has been estimated at $0.4 \%{ }^{4}$.

The presence of the peritoneal adhesions can determine multiple intra- or postoperative complications, the adhesiolysis prolonging the operative time and the hospital stay, increasing the risk of conversion ${ }^{5,6}$.

The aim of the present study is to evaluate the impact of the peritoneal adhesions, identified during laparoscopic cholecystectomy, on the postoperative evolution of the patients.

\section{MATERIAL AND METHOD}

The present study used anonymous data taken from the InfoWord Data Base of the General Surgery Department of the "Sfântul Pantelimon" Emergency Hospital from Bucharest, Romania.

The results were used in order to identify the patients undergoing laparoscopic cholecystectomy between January 2014 and October 2018, their evolution being followed-up for approximately 16 months.

The study group was conducted after searching the patients' data in the InfoWord database using the ICD10 diagnostic codes (International Code of Disease 10 ${ }^{\text {th }}$ Edition: K81.0- Acute Cholecystitis, K66.0- Peritoneal Adhesions) and the ROv1DRG Surgical Codes (J10102 - laparoscopic cholecystectomy,J12202 - laparoscopic adhesiolysis, J10103 - open cholecystectomy after laparoscopic attempt), thus providing information on the aetiology and the surgical intervention. Taking into consideration the data resulted, the patients were divided into two groups: the case group, represented by those who had postoperative peritoneal adhesions at the time of the laparoscopic cholecystectomy, and the control group, consisting of those in whom the peritoneal adhesions were not identified intraoperatively.

Using the variables resulted from the analysis of the database, the risk of intra- and postoperative complications was estimated. The long-term evolution of the patients has been evaluated by strict monitoring of the continuous or day hospitalizations in the General Surgery Department and the reasons for these readmissions, between January 2014 and October 2018.

The principle of individual patient confidentiality has been respected. The informed consent of each patient, for any diagnostic maneuver or therapeutic procedure, has been obtained. The study protocol respects the ethical guidelines of the Declaration of Ethics adopted by the $18^{\text {th }}$ WMA General Assembly, Helsinki, Finland, June 1964, and amended by WMA General Council of Fortaleza, Brazil, 2013 at the $64^{\text {th }}$ edition (64 $4^{\text {th }}$ WMA General Assembly, Fortaleza, Brazil, October 2013).

Data on demographics, diagnosis, duration of hospitalization, complications and mortality rate were analyzed, the statistical processing being created using Microsoft Office Excel Software 2013.

\section{RESULTS}

Between January 2014 and October 2018, there were 1407 patients undergoing laparoscopic cholecystectomy, admitted in the General Surgery Department of the "Sfântul Pantelimon" Emergency Clinical Hospital from Bucharest. For 537 patients with known surgical history, out of a total of 1407 , peritoneal adhesions were identified during laparoscopic cholecystectomy (Figure 1), the remaining 870 cases having no peritoneal adhesions.

The demographic characteristics of the population (mean age, mean body mass index (BMI), female: male ratio (F: M), surgical history, and mean ASA score (American Society of Anesthesiology) presented no statistically significant differences between the case and the control group (Table 1).

The presence of the peritoneal adhesions determines an increased operative time and a higher risk of converting the laparoscopic cholecystectomy to open surgery (Table 2). Intraoperative complications that required the conversion of the laparoscopic intervention were represented by: accidental intra-operative enterotomy, iatrogenic lesions of the main bile ducts, difficult adhe- 
Figure 1. Postoperative peritoneal adhesion bands between right the parietal peritoneum and the right colic wall identified during laparoscopic cholecystectomy (patient with personal history of appendectomy) (personal collection).

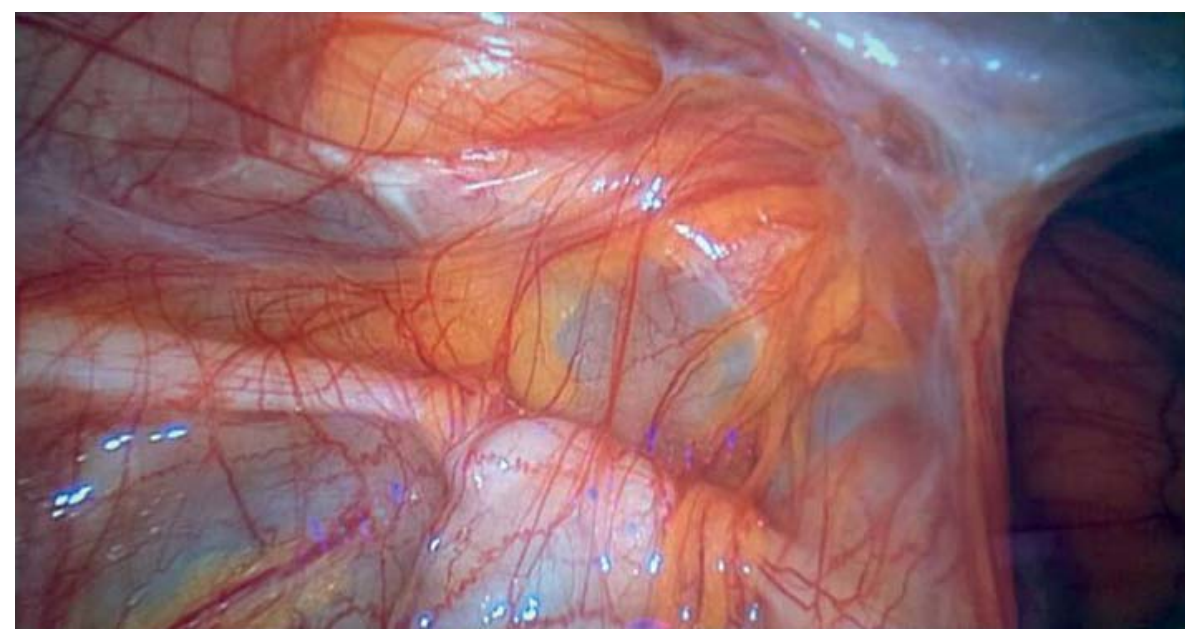

siolysis, poor control of the bleeding, iatrogenic lesions during the positioning of the trocars and technical errors.

The rate of conversion to laparotomy is $9.31 \%$ in the case group and $0.8 \%$ in the control group (Figure 2), a

Table 1. The demographic characteristics of the study population

\begin{tabular}{|l|c|c|}
\hline Demographic variables & $\begin{array}{c}\text { Case group } \\
\text { (537 patients) }\end{array}$ & $\begin{array}{c}\text { Control group } \\
\text { (870 patients) }\end{array}$ \\
\hline Mean age (years) \pm SD & $65 \pm 13.2$ & $59.1 \pm 12.4$ \\
\hline Mean BMI \pm SD & $28 \pm 3.15$ & $27 \pm 2.9$ \\
\hline Female: Male ratio & $348: 189$ & $491: 379$ \\
\hline Surgical history & $100 \%$ & $8.1 \%$ \\
\hline Mean ASA score \pm SD & $2.53 \pm 0.7$ & $2.31 \pm 0.65$ \\
\hline
\end{tabular}

Figure 2. The rate of conversion of the laparoscopic cholecystectomy to laparotomy in the case and control groups.
Table 2. The intraoperative characteristics of the study population

\begin{tabular}{|l|c|c|}
\hline Intraoperative variables & $\begin{array}{c}\text { Case group } \\
\text { (537 patients) }\end{array}$ & $\begin{array}{c}\text { Control group } \\
\text { (870 patients) }\end{array}$ \\
\hline $\begin{array}{l}\text { Mean operative time } \\
\text { (minutes) }\end{array}$ & $131 \pm 62$ & $92 \pm 54$ \\
\hline Conversion rate & $50(9.31 \%)$ & $7(0.8 \%)$ \\
\hline $\begin{array}{l}\text { Accidental intraoperative } \\
\text { enterotomy }\end{array}$ & $2(0.37 \%)$ & $1(0.11 \%)$ \\
\hline $\begin{array}{l}\text { latrogenic lesions of the } \\
\text { common bile duct }\end{array}$ & $4(0.74 \%)$ & $1(0.11 \%)$ \\
\hline Difficult adhesiolysis & $31(5.77 \%)$ & $1(0.11 \%)$ \\
\hline Poor bleeding control & $8(1.5 \%)$ & $4(0.45 \%)$ \\
\hline Trocar- induced lesions & $3(0.56 \%)$ & - \\
\hline Technical errors & $2(0.37 \%)$ & - \\
\hline
\end{tabular}


higher frequency of intraoperative complications in the first group compared to the second group being observed, which suggests a correlation between the presence of the peritoneal adhesions and the risk of intraoperative incidents and accidents.

A prolonged operative time has been observed for patients with peritoneal adhesions (case group - Figure 3).

The rate of the postoperative complications is higher in the case group, in comparison with the control group (Table 3).

\section{Table 3. The postoperative complications in the study groups}

\begin{tabular}{|l|c|c|}
\hline Postoperative complications & $\begin{array}{c}\text { Case group } \\
\text { (537 patients) }\end{array}$ & $\begin{array}{c}\text { Control group } \\
\text { (870 patients) }\end{array}$ \\
\hline Wound dehiscence & $1(0.18 \%)$ & - \\
\hline $\begin{array}{l}\text { Postoperative wound } \\
\text { infection }\end{array}$ & $76(14.15 \%)$ & $71(8.16 \%)$ \\
\hline $\begin{array}{l}\text { Haemorrhagic gastro- } \\
\text { duodenal ulcer }\end{array}$ & $2(0.37 \%)$ & $1(0.11 \%)$ \\
\hline Intestinal obstruction & $1(0.18 \%)$ & $1(0.11 \%)$ \\
\hline $\begin{array}{l}\text { Infectious colitis (Clostridium } \\
\text { Difficile) }\end{array}$ & $3(0.56 \%)$ & $2(0.22 \%)$ \\
\hline Biliary fistula/ Bilioma & $4(0.74 \%)$ & $1(0.11 \%)$ \\
\hline Subhepatic hematoma & $4(0.74 \%)$ & $2(0.22 \%)$ \\
\hline Subhepatic abscess & $3(0.56 \%)$ & $1(0.11 \%)$ \\
\hline Recurrent bile duct lithiasis & $6(1.11 \%)$ & $1(0.11 \%)$ \\
\hline Thrombo-embolic accidents & $2(0.37 \%)$ & $2(0.22 \%)$ \\
\hline $\begin{array}{l}\text { Post-cholecystectomy } \\
\text { syndrome }\end{array}$ & $12(2.23 \%)$ & $18(2.06 \%)$ \\
\hline
\end{tabular}

Table 3 shows that there is no statistically significant impact of the peritoneal adhesions on the risk of postoperative complications.

The data presented in Table 4 shows the prolonging effect of the peritoneal adhesions upon hospitalization, adding an average of two days to the mean hospitalization of the patients who have no peritoneal adhesions. Higher rates of readmission and reintervention in the first 30 postoperative days have been demonstrated in the case group. The peritoneal adhesions identified during laparoscopic cholecystectomy do not influence the in- hospital mortality rate, according to the results of the present study.

By summarizing the data obtained, an increased operative time, a higher risk of conversion, a prolonged hospitalization and a higher risk of readmission or reintervention in the first 30 days have been observed in patients with postoperative peritoneal adhesions iden-

Table 4. Average hospitalization, in-hospital mortality rate, and readmission or reintervention rate in the first 30 days, in case and control groups

\begin{tabular}{|l|c|c|}
\hline Postoperative variables & $\begin{array}{c}\text { Case group } \\
\text { (537 patients) }\end{array}$ & $\begin{array}{c}\text { Control group } \\
\text { (870 de patients) }\end{array}$ \\
\hline $\begin{array}{l}\text { Mean hospitalization time } \\
\text { (days) }\end{array}$ & $8 \pm 2$ & $6 \pm 1.5$ \\
\hline In-hospital mortality rate & $1(0.18 \%)$ & $1(0.11 \%)$ \\
\hline$<30$ days Readmission risk & $33(6.14 \%)$ & $17(1.95 \%)$ \\
\hline $\begin{array}{l}<30 \text { days Reintervention } \\
\text { risk }\end{array}$ & $19(3.53 \%)$ & $7(0.8 \%)$ \\
\hline
\end{tabular}

Figure 3. An increased operative time for patients diagnosed with peritoneal adehsion syndrome at the time of the laparoscopic cholecystectomy.

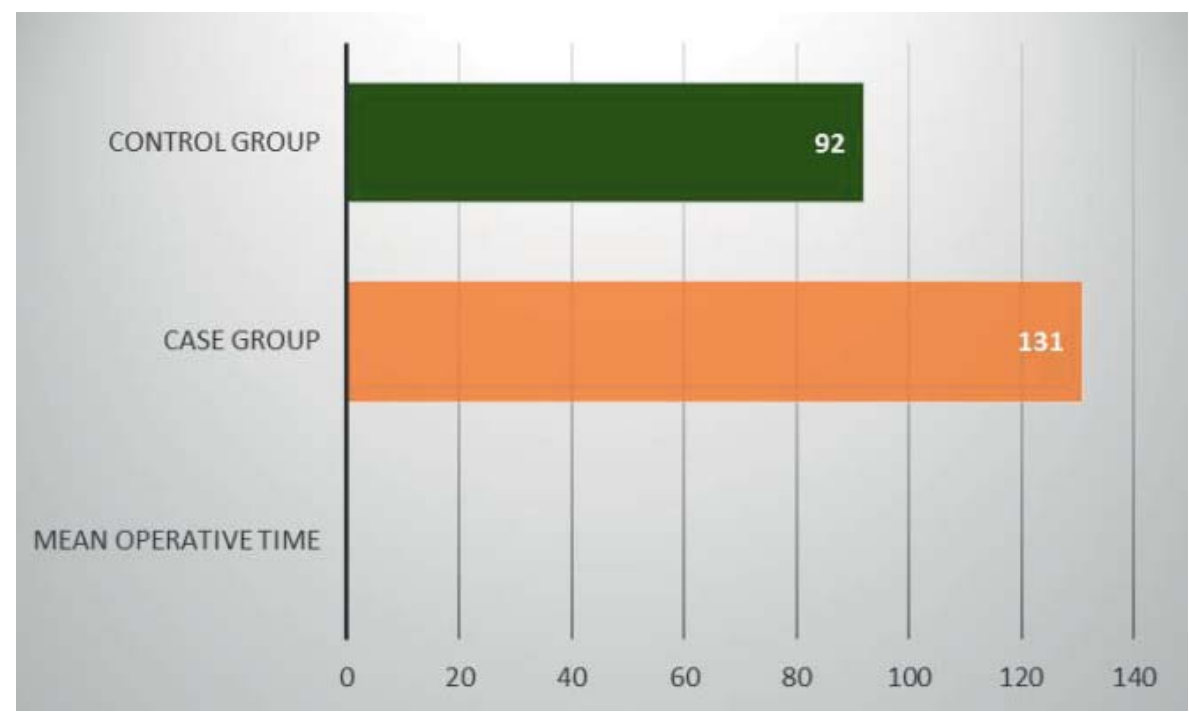




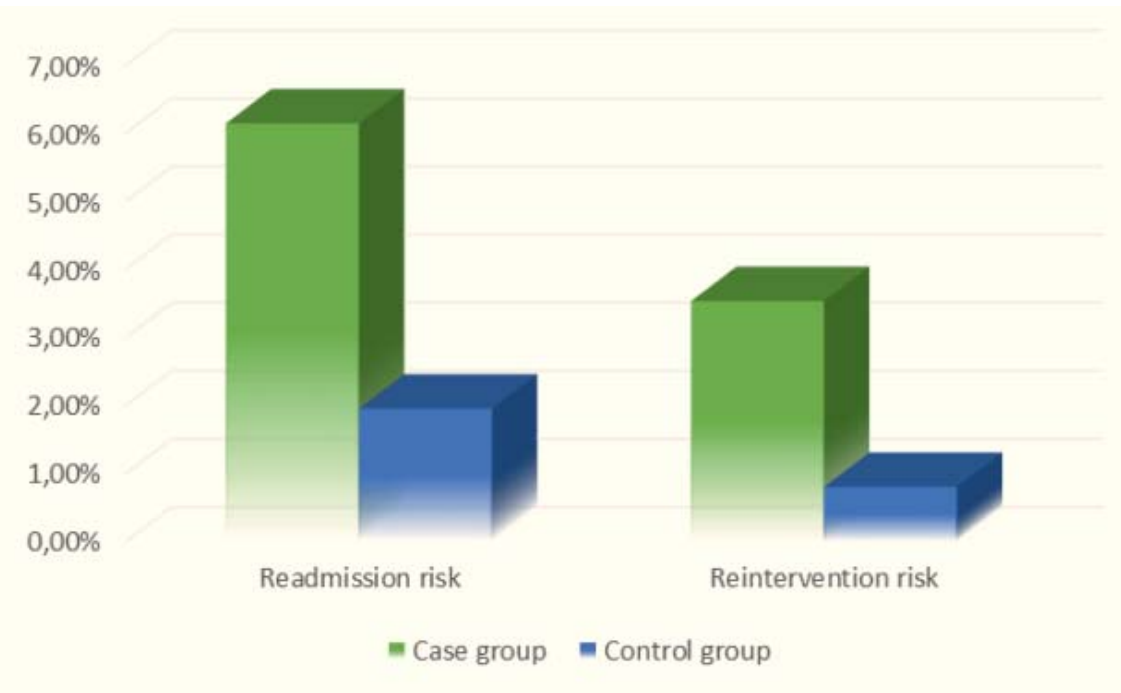

Figure 4. Readmission and reintervention risks in the first postoperative days.

tified at the time of the laparoscopic cholecystectomy (Figure 4).

\section{DISCUSSION}

The clinical consequences and the possible complications of the postoperative peritoneal adhesions represent highly studied topics in the medical field. The data from the literature regarding the impact of the postoperative peritoneal adhesions on the evolution of the patients with personal surgical history, who will be subjected to laparoscopic cholecystectomy, is, however, limited.

The purpose of the study is to evaluate the impact of the peritoneal adhesions on the perioperative evolution of the patients undergoing laparoscopic cholecystectomy. The comparative analysis of the intra- and postoperative data has shown that adhesiolysis leads to a prolonged operative time, to an increased risk of conversion to the classical method, to a longer hospital stay and a higher risk of readmission or reintervention.

The association between the presence of the peritoneal adhesions at the time of the surgical intervention and the prolonged operative time is sustained by multiple recent studies ${ }^{7,8}$.

Schwartz et al. demonstrated an increased risk of conversion in the presence of peritoneal adhesions?.

The longer hospital stay with no increase of the incidence of postoperative complications suggests a delay in the postoperative recovery of the patients with adhesions, secondary to adhesiolysis, similar results being recently published ${ }^{10,11}$.
The limits of this study are represented by its retrospective design and the high potential of reporting errors, the data being collected through operative protocols and discharge papers, the high degree of subjectivity involved in the process of identifying and describing the peritoneal adhesions being already known. In order to overcome the limits of the study, it is necessary to develop a prospective study on a large group of patients, based on a standardized method of classification of the peritoneal adhesions.

Taking into account the study population, that included a significant number of patients (1407), valid conclusions can be elaborated following the statistical analysis of the data. Thus, a minimal impact of the preexisting peritoneal adhesions on the risk of early postoperative complications has been proven. According to the results of the present study, the preexisting postoperative peritoneal adhesions can increase the operative time, the conversion rate, the duration of the hospitalization and the risk of readmission or surgical reintervention.

\section{CONCLUSIONS}

- Pre-existing postoperative peritoneal adhesions discovered during laparoscopic cholecystectomy do not influence the risk of early postoperative complications.

- Pre-existing postoperative peritoneal adhesions increase the operative time and the hospital stay, due to delayed return of the bowel function that 
may occur in patients undergoing prolonged anesthetic and surgical procedures, as in the cases that need elaborate adhesiolysis.

- The peritoneal adhesions determine a higher risk of conversion of the laparoscopic procedures to open surgery.

- The risk of readmission or reintervention in the first postoperative days is greatly increased in the presence of the postoperative peritoneal adhesions.

\section{References}

1. Liakakos T, Thomakos N, Fine PM, et al. Peritoneal adhesions: etiology, pathophysiology, and clinical significance. Recent advances in prevention and management. Dig Surg 2001;18: 260-73.

2. Beck DE, Opelka FG, Bailey HR, et al. Incidence of small-bowel obstruction and adhesiolysis after open colorectal and general surgery. Dis Colon Rectum 1999;42:241-8.

3. Meagher AP, Farouk R, Dozois RR, et al. J ileal pouch-anal anastomosis for chronic ulcerative colitis: complications and longterm outcome in 1310 patients. Br J Surg 1998;85:800-3.

4. Angenete $E$, Jacobsson A, Gellerstedt M, Haglind E. Effect of Laparoscopy on the Risk of Small-Bowel ObstructionA Population-Based Register Study. Arch Surg. 2012;147(4):359-365. doi:10.1001/archsurg.2012.31

5. Ehrenfeld JM, Seim AR, Berger DL, Sandberg WS. Implementation of a direct-from-recovery-room discharge pathway: a process improvement effort. Dis. Colon Rectum 2009;43:1297-9.

6. van Goor HH. Consequences and complications of peritoneal
Compliance with ethics requirements: The authors declare no conflict of interest regarding this article. The authors declare that all the procedures and experiments of this study respect the ethical standards in the Helsinki Declaration of 1975, as revised in 2008(5), as well as the national law. Informed consent was obtained from all the patients included in the study.

adhesions. Colorectal Dis 2007;9(Suppl 2):25-34. Binenbaum SJ, Goldfarb MA. Inadvertent enterotomy in minimally invasive abdominal surgery. JSLS 2006;10:336-40.

7. Coleman MG, McLain AD, Moran BJ. Impact of previous surgery on time taken for incision and division of adhesions during laparotomy. Dis Colon Rectum 2000;43:1297-9.

8. Beck DE, Ferguson MA, Opelka FG, et al. Effect of previous surgery on abdominal opening time. Dis Colon Rectum 2000;43: 1749-53.

9. Schwartz ML, Drew RL, Chazin-Caldie M. Factors determining conversion from laparoscopic to open Roux-en-Y gastric bypass. Obes Surg 2004;14:1193-7.

10. Van Der Krabben AA, Dijkstra FR, Nieuwenhuijzen M, et al. Morbidity and mortality of inadvertent enterotomy during adhesiotomy. Br J Surg 2000;87:467-71.

11. Ramzi A, Hannah C, et al. The impact of adhesions on operations and postoperative recovery in colon cancer surgery. The American Journal of Surgery (2013) 206, 2, Pp. 166-171. 